\title{
ANALISIS FOREIGN DIRECT INVESTMENT (FDI) INDONESIA DI NIGERIA PERIODE 2014-2017: STUDI KASUS PT. INDOFOOD SUKSES MAKMUR*
}

\author{
Fitri Chaerunisa \\ Universitas Pembangunan Nasional "Veteran" Jakarta \\ Email: fitrichaerunisa14@gmail.com
}

\begin{abstract}
Liberalism in international trading opens the opportunity for any country to sell their products to the whole world. One of the activities that cannot be separated from international trading is Foreign Direct Investment (FDI). Nigeria is one of many countries which really welcome the concept of FDI. There are Indonesian corporations that have been investing in Nigeria, one of them is PT. Indofood Sukses Makmur. With the Toleram Group from Singapore, the company has built a new corporation together, called De United Foods Industries Ltd (DUFIL). FDI concept and Product Life Cycle (PLC) theory are used in this research, along with the qualitative method and descriptive technique of data analysis. The result shows that PT. Indofood Sukses Makmur (De United Foods Industries Ltd) is a company with horizontal FDI model. The company classified in greenfield FDI category, which developed with merger. According to PLC theory, instant noodle from PT. Indofood Sukses Makmur which has been produced by De United Foods Industries Ltd in Nigeria is currently in the mature step.
\end{abstract}

Keywords: Foreign Direct Investment (FDI), Indonesia, Nigeria, Product Life Cycle (PLC), Indofood

\begin{abstract}
Abstrak
Liberalisme perdagangan internasional membuka peluang bagi negara manapun untuk menjual hasil produksinya ke seluruh dunia. Salah satu aktivitas perekonomian yang tidak dapat dilepaskan dari perdagangan internasional adalah aktivitas aliran modal (FDI). Nigeria merupakan salah satu negara yang sangat terbuka dengan konsep FDI. Beberapa perusahaan Indonesia telah berinvestasi di Nigeria, salah satunya adalah PT. Indofood Sukses Makmur. Bersama dengan Grup Toleram dari Singapura, perusahaan tersebut mendirikan sebuah perusahaan baru di Nigeria dengan nama De United Foods Industries Ltd (DUFIL). Konsep FDI dan Siklus Kehidupan Produk digunakan dalam penelitian bersamaan dengan metode kualitatif dan teknik analisis data deskriptif. Hasil penelitian menunjukkan bahwa PT. Indofood Sukses Makmur (De United Foods Industries Ltd) merupakan perusahaan dengan model FDI horizontal. Perusahaan ini termasuk dalam kategori FDI greenfield yang pada perkembangannya, terjadi proses merger. Menurut teori Siklus Hidup Produk, produk mie instan milik PT. Indofood Sukses Makmur yang diproduksi oleh De United Foods Industries Ltd di Nigeria berada pada tahap kematangan.
\end{abstract}

Kata kunci: Foreign Direct Investment (FDI), Indonesia, Nigeria, Siklus Kehidupan Produk, Indofood 
Pendahuluan

Liberalisme

perdagangan

internasional membuka peluang bagi negara manapun untuk menjual hasil produksinya ke seluruh dunia. Hal tersebut tentu membuka keran ekspor dan impor bagi seluruh negara di dunia. Tidak dapat dipungkiri bahwa dewasa ini, perdagangan internasional sangat berpengaruh terhadap keadaan ekonomi suatu negara.

Salvatore dalam (Safitriani, 2014) mengemukakan bahwa salah satu aktivitas perekonomian yang tidak dapat dilepaskan dari perdagangan internasional adalah aktivitas aliran modal, baik yang sifatnya masuk maupun keluar, dari suatu negara. Kemungkinan terjadinya perpindahan faktor-faktor produksi dari negara eksportir ke negara importir menjadi besar akibat aktivitas perdagangan internasional berupa kegiatan ekspor dan impor. Hal ini disebabkan oleh perbedaan biaya dalam proses perdagangan internasional. Perpindahan faktor-faktor produksi dari negara eksportir ke negara importir ini umumnya terjadi dalam bentuk Foreign Direct Investment (FDI).

Nigeria merupakan salah satu negara yang sangat terbuka dengan investasi asing. Dengan diterbitkannya UndangUndang NIPC Nomor 16 Tahun 1995, Nigeria telah mengatur regulasi investasi sejak lebih dari dua puluh tahun lalu.
Upaya untuk meliberalisasi lingkungan bisnis memang dilakukan secara sengaja oleh pemerintah Nigeria untuk mengakomodasi sektor swasta sebagai mesin pertumbuhan ekonomi. Berikut ini yang merupakan poin-poin penting Undang-Undang NIPC.

a) Menciptakan landasan hukum bagi kerangka investasi yang liberal dan sangat terbuka. Undang-undang ini merupakan undang-undang lintas sektoral yang bertujuan untuk mendorong masuknya investasi asing di semua sektor ekonomi.

b) Tidak ada batasan izin asing untuk berinvestasi dan berpartisipasi dalam operasi dari setiap perusahaan Nigeria.

c) Izin 100 persen kepemilikan asing dari perusahaan. Namun, di sektor minyak dan gas, investasi tetap terbatas pada usaha patungan atau perjanjian pembagian produksi.

d) Memungkinkan repatriasi laba atau dividen ke negara asal dalam mata uang yang dapat dikonversi.

Undang-Undang NIPC tersebut juga melandasi dibentuknya Komisi Promosi Investasi Nigeria (Nigerian Investment Promotion Commission alias NIPC) yang pada 2016 menyatakan beberapa alasan untuk berinvestasi di Nigeria yakni sebagai berikut. 
a) Sumber daya yang berlimpah

Nigeria memiliki sumber daya yang luar biasa besar, kebanyakan belum benar-benar dimanfaatkan. Sumber daya tersebut diantaranya adalah sumber daya mineral, pertanian, dan manusia.

b) Pasar yang luas

Nigeria menawarkan pasar di subSahara Afrika dengan populasi sekitar 180 juta orang. Potensi pasar Nigeria juga meluas ke Afrika bagian barat.

c) Stabilitas politik

Nigeria memiliki lingkungan perpolitikan yang stabil.

d) Ekonomi pasar bebas

Pemerintah Nigeria telah menciptakan iklim yang baik untuk bisnis dan usaha industri. Prosedur administratif dan birokrasi telah diatur sedemikian rupa menjadi sangat sederhana. Pemerintah Nigeria telah menerapkan kebijakan dan program yang menjamin ekonomi pasar bebas.

e) Sektor swasta yang kuat

Nigeria memiliki sektor swasta yang dinamis, yang telah menjamin tanggung jawab yang lebih besar di bawah lingkungan ekonomi baru. f) Aliran investasi gratis

Liberalisasi telah dilakukan dalam exchange control regulations guna memastikan aliran bebas keuangan internasional. Kini, ada pergerakan modal investasi yang tidak terbatas.

g) Insentif yang menarik

Rangkaian insentif yang menarik telah disiapkan guna menarik investasi.

h) Sektor keuangan yang cepat bertumbuh

Sektor perbankan dan keuangan berkembang dengan baik. Investor memiliki akses mudah untuk modal dan fasilitas kredit lainnya.

i) Tenaga kerja ahli yang murah

Nigeria memiliki tenaga kerja ahli yang melimpah dengan harga upah yang ekonomis. Ini menjadikan Nigeria sebagai salah satu negara dengan biaya produksi paling rendah di Afrika.

j) Infrastruktur

Nigeria memiliki perkembangan yang cepat dalam infrastruktur fisik dan industri, khususnya transportasi, komunikasi, listrik dan pasokan air 
Tanpa mengesampingkan klaim di atas, Nigeria telah menjadi pasar yang

\begin{tabular}{|c|c|c|c|c|}
\hline \multirow{2}{*}{ Negara } & \multicolumn{4}{|c|}{ FDI net inflows (juta dolar AS) } \\
\cline { 2 - 5 } & $\mathbf{2 0 1 4}$ & $\mathbf{2 0 1 5}$ & $\mathbf{2 0 1 6}$ & $\mathbf{2 0 1 7}$ \\
\hline Mesir & 4.612 & 6.925 & 8.107 & 7.392 \\
\hline Nigeria & 4.694 & 3.064 & 4.449 & 3.503 \\
\hline $\begin{array}{c}\text { Afrika } \\
\text { Selatan }\end{array}$ & 5.771 & 1.729 & 2.235 & 1.325 \\
\hline $\begin{array}{c}\text { Republik } \\
\text { Afrika } \\
\text { Tengah }\end{array}$ & 3 & 3 & 7 & 17 \\
\hline
\end{tabular}

Tabel 1: FDI net inflows Nigeria periode 20142017

sangat potensial mengingat jumlah penduduknya yang sangat tinggi sekaligus paling tinggi di Benua Afrika, yakni sebanyak 186 juta jiwa (BBC, 2018).

Dalam perkembangannya, Nigeria memiliki nilai FDI net inflows yang dinamis. Data milik United Nations Conference on Trade and Development (UNCTAD) yang tertulis pada Tabel 1 menunjukkan angka yang stabil pada FDI inflows Nigeria. Mesir merupakan salah satu negara dengan FDI inflows tertinggi pada tahun 2016, sedangkan salah satu FDI inflows terendah dimiliki oleh Republik Afrika Tengah. Nigeria sendiri berada di tengah kedua kondisi tersebut. Berdasarkan data tersebut, rata-rata nilai FDI inflows Nigeria selama periode 2014-2017 lebih tinggi dari rata-rata nilai FDI inflows Afrika Selatan pada periode yang sama dengan selisih 1.162,5 juta dolar AS.

Nigeria menduduki posisi ketiga dalam aliran FDI terbesar di Afrika tahun 2016 dengan perolehan nilai FDI inflows sebesar 4.4 milyar dolar AS, dan kenaikan sebesar 45,2\% dari tahun sebelumnya. Angola berdiri pada posisi pertama dengan FDI inflows sebesar 14.4 milyar dolar AS meskipun turun $11,2 \%$ dari tahun sebelumnya. Selanjutnya, Mesir dengan perolehan FDI inflows sebesar 8,1 milyar dolar AS, dan kenaikan sebesar 17,1\%. Dua posisi di bawah Nigeria ditempati oleh Ghana dan Ethiopia yang masingmasing memperoleh 3,5 dan 3,2 milyar dolar AS sebagai FDI inflows, dan secara berurutan mengalami kenaikan sebesar 9,2\% dan $45,8 \%$ dari tahun sebelumnya (UNCTAD, 2017).

Nigeria memiliki beberapa sektor yang menjadi prioritas mereka. Sektor tersebut ialah pertanian, kelistrikan, mineral solid, kesehatan, otomotif, pengemasan, manufaktur ringan, serta outsourcing (NIPC, 2018).

Nigeria, selain memiliki potensi pasar yang besar, juga memiliki prospek perdagangan yang menjanjikan untuk Indonesia. Apalagi mengingat hubungan bilateral yang terjalin dengan baik. Sebagaimana yang tertulis pada halaman resmi Kementrian Luar Negeri Republik 
Indonesia,

hubungan

diplomatik

Indonesia-Nigeria dibuka pada tahun 1965 dan sejak saat itu Indonesia mempunyai Kedutaan Besar di Lagos (sejak tahun 2008 pindah ke Abuja), sedangkan Kedutaan Besar Nigeria di Jakarta dibuka pada tahun 1976. Hubungan kedua negara hingga saat ini berjalan dengan baik dan terus meningkat. Hal ini didasarkan atas kenyataan bahwa kedua negara sama-sama anggota GNB, OKI, kelompok 77, G15, D-8, OPEC, PBB, anti apartheid, anti kolonialisme dan imperialisme serta samasama berusaha mewujudkan Tata Informasi Dunia Baru.

Hubungan dagang Indonesia dengan Nigeria tergolong baik, sekalipun pasca krisis ekonomi global 2008. Menurut Kementrian Luar Negeri Republik Indonesia, meskipun sempat mengalami penurunan volume pada tahun 2006 dan 2008, pada tahun 2009 terjadi kembali peningkatan yang signifikan dalam perdagangan Indonesia-Nigeria. Tabel 2 di bawah ini menunjukkan informasi data

\begin{tabular}{|c|c|c|c|c|}
\hline \multirow{2}{*}{ Uraian } & \multicolumn{4}{|c|}{ Tahun } \\
\hline & 2014 & 2015 & 2016 & 2017 \\
\hline Total perdagangan & $3.955 .093,4$ & $1.733 .894,2$ & $1.598 .786,4$ & $1.631 .536,3$ \\
\hline Migas & $3.286 .391,5$ & $1.284 .810,1$ & $1.280 .296,5$ & $1.253 .193,6$ \\
\hline Non migas & $668.701,8$ & $449.084,1$ & $318.489,9$ & $378.342,7$ \\
\hline Ekspor & $648.792,7$ & $445.738,3$ & $310.819,2$ & $342.387,7$ \\
\hline Migas & 331,0 & 317,2 & 216,3 & 160,8 \\
\hline Non migas & $648.461,6$ & $445.421,1$ & $310.602,9$ & $342.226,9$ \\
\hline Impor & $3.306 .300,7$ & $1.288 .155,8$ & $1.287 .967,2$ & $1.289 .148,6$ \\
\hline Migas & $3.286 .060,5$ & $1.284 .492,9$ & $1.280 .080,2$ & $1.253 .032,8$ \\
\hline Non migas & $20.240,2$ & $3.663,0$ & $7.887,0$ & $36.115,8$ \\
\hline Neraca perdagangan & $2.657 .508,0$ & $-842.417,5$ & $-977.148,0$ & $-946.761,0$ \\
\hline $\mathrm{M}^{---}$Tabel 2: $\mathrm{I}$ & noe 7ñe & $\begin{array}{l}1004172< \\
\text { nangan }\end{array}$ & donesia & ingan \\
\hline$\overline{N_{1}}$ & Jigeria $\mathrm{Pe}$ & ode 2014 & -2017 & \\
\hline
\end{tabular}

neraca perdagangan Indonesia dengan Nigeria periode 2014-2016 (Kementrian Perdagangan Republik Indonesia, 2017).

Selain ekspor, beberapa perusahaan Indonesia juga telah berinvestasi di Nigeria. Tercatat ada 26 perusahaan asal Indonesia yang telah menanamkan modalnya di Nigeria dengan mendirikan perusahaan dan pabrik di negara tersebut. Salah satu perusahaan yang telah berinvestasi di sana ialah PT. Indofood Sukses Makmur. Perseroan Terbatas Indofood Sukses Makmur mulai berinvestasi di Nigeria pada tahun 1996 (Ningsih S., 2016). Perusahaan ini mendirikan De-United Food Industry Ltd bersama Grup Tolaram (Singapura) dan membuka 2 (dua) pabrik mie instan dengan merk Indomie di Otta (Negara Bagian Ogun) dan Port Harcourt (Negara Bagian Rivers). Produk mie instan milik PT. Indofood Sukses Makmur pada 2017 telah menguasai $70 \%$ pasar Nigeria (Sugianto, 2017) dan (Fauzi, 2017). Adapun perolehan pendapatan perseroan ini mencapai Rp 66,75 triliun pada 2016.

Indomie sebagai produk mie instan yang populer di Nigeria ternyata tidak semata-mata langsung melejit di sana. Pada dekade 80-an, PT. Indofood Sukses Makmur mengekspor produk mereka kepada Dufil Prima Foods, produsen pangan Nigeria. Ketika itu, tidak ada satu 
pun pesaing untuk produk mie instan di Nigeria. Pengenalan produk di negara ini tergolong sulit, karena warga Nigeria tidak memiliki budaya makan mie sebelumnya. Hampir tidak ada orang yang tahu apa itu mie instan di Nigeria saat itu. Pemasaran dengan klaim bahwa mie instan adalah setara dengan gandum atau beras, serta pembuatan komik "The Indomitable" juga dilakukan guna menarik konsumen (Wargadiredja, 2017).

Kesamaan status Nigeria dan Indonesia sebagai negara mayoritas muslim juga turut membantu dalam membuat proses masuknya merek Indomie yang sejak awal memasang label halal di Nigeria menjadi lebih mudah. Faktor lain yang melanggengkan eksistensi Indomie di Nigeria ialah, saat Nigeria dilanda krisis sekitar tahun 2015-2016, harga beras yang merupakan makanan pokok di Nigeria melonjak. Masyarakat lebih memilih Indomie sebagai makanan pokok mereka selama periode itu karena harga Indomie lebih murah ketimbang beras (Wargadiredja, 2017).

Selain itu, Indomie yang dipasarkan di Nigeria juga berbeda dengan Indomie yang dipasarkan di Indonesia. Dilansir tempo.co, Menteri Luar Negeri Indonesia telah memberikan keterangan mengenai Indomie yang beredar di Nigeria. Ukuran Indomie di Nigeria sangat besar, hampir 3 kali lebih besar dari ukuran Indomie yang beredar di pasar Indonesia. Dalam laman resmi De United Food Industry, terdapat beberapa informasi mengenai produk Indomie yang beredar di sana. Varian rasa Indomie yang beredar di Nigeria didominasi oleh rasa ayam. Namun ada satu varian rasa yang unik, yakni varian rasa oriental. Ukuran Indomie pada umumnya berkisar antara 100-120 gram, namun ada varian Indomie yang dijual dengan ukuran 70 gram (Indomitables Pack Chicken Flavor) dan 210 gram (Indomie Hungry Man Size). Pada tampilan di kemasannya, Indomie di Nigeria tampak "pucat", yang mengartikan bahwa bumbu yang digunakan pun berbeda. Bumbu Indomie di Nigeria tidak sekuat Indomie yang beredar di Indonesia (M. P., 2017).

\section{Saat ini, De United Food Industry} Ltd memiliki skala terbesar di seluruh Benua Afrika. Laba kotor dari penjualan Indomie saja mencapai 600 juta dolar AS (setara $\operatorname{Rp~7,8~triliun)~per~tahun~di~Afrika.~}$ Ini membuatnya masuk dalam jajaran merek urutan ke-8 paling banyak dibeli di seluruh dunia berdasarkan riset Kantar Worldpanel (Wargadiredja, 2017).

Berdasarkan uraian di atas, dapat ditarik sebuah pertanyaan yang sekaligus menjadi rumusan masalah dalam penelitian ini yakni, bagaimanakah analisis Investasi 
Asing Langsung (Foreign Direct Investment atau FDI) PT. Indofood Sukses Makmur di Nigeria pada periode 20142017? Penelitian ini bertujuan untuk menganalisis FDI Indonesia di Nigeria, khususnya PT. Indofood Sukses Makmur, pada periode 2014-2017 serta menghasilkan perkiraan atas komoditas yang dibutuhkan oleh Nigeria di masa yang akan datang. Penelitian ini bermanfaat bagi pemerintah untuk menentukan komoditi apa yang lebih berpotensi untuk diinvestasikan oleh pemerintah maupun pengusaha lokal ke Nigeria.

\section{Kajian Pustaka}

\section{Foreign Direct Investment (FDI)}

Foreign Direct Investment (FDI) adalah elemen kunci dalam integrasi ekonomi internasional yang berkembang pesat saat ini, di era globalisasi. FDI menyediakan sarana untuk menciptakan hubungan langsung, stabil dan tahan lama antar ekonomi. Dengan kebijakan yang tepat, FDI dapat berfungsi sebagai kendaraan guna mengembangkan perusahaan lokal serta dapat membantu memperbaiki kompetisi baik untuk penerima maupun investor itu sendiri. Secara khusus, FDI mendorong transfer teknologi dan pengetahuan dalam sektor ekonomi. FDI juga memberikan peluang bagi penerima (tuan rumah) untuk mempromosikan produknya secara lebih luas di pasar internasional. FDI merupakan sumber modal penting untuk berbagai negara tuan rumah dan investor (OECD, 2008).

FDI terbagi menjadi FDI vertikal dan horizontal (Nayak dan Choudhury, 2014). FDI vertikal merupakan situasi di mana perusahaan induk berinvestasi di fasilitas produksi di negara lain untuk menghasilkan input yang akan dibawa kembali ke perusahaan induk untuk diproses lebih lanjut. Sebagai alternatif, perusahaan di negara asal hanya memproduksi input dan mengirimkannya ke afiliasinya di negara lain untuk melayani pasar tersebut. Di sisi lain, FDI horizontal mengacu pada investasi dalam produksi di luar negeri yang dirancang untuk melayani konsumen asing.

Helpman dalam (Nayak dan Choudhury, 2014) mengemukakan sebuah model kesetimbangan umum (general equilibrium model) dalam perdagangan internasional. Ia menyatakan bahwa perusahaan multinasional (Multinational Corporations atau MNC) memiliki peran yang penting dalam perdagangan internasional. Helpman menggabungkan unsur kepemilikan dan lokasi. Teorinya ini disasari oleh pemahaman bahwa perusahaan memiliki satu fasilitas 
produksi yang bisa saja berada di negara lain (bukan di negara tempat perusahaan pusat berdiri). Namun, ini berarti perusahaan tersebut tidak akan pernah membuka lebih dari satu fasilitas, disebabkan oleh tidak adanya tarif dan biaya transportasi, melainkan biaya untuk merawat fasilitas itu sendiri. Ini menjadikan model tersebut tampak sebagai salah satu perusahaan yang benar-benar terintegrasi secara vertikal.

Dalam tulisannya yang lain, Helpman, dan beberapa ahli lain memfokuskan topik pada pilihan perusahaan antara ekspor dan FDI horizontal (Nayak dan Choudhury, 2014). Mereka mendasari pemikiran pada konsep bahwa setiap industri adalah heterogen. Dengan begitu, maka produktivitas tiaptiap perusahaan akan berbeda satu sama lain. Pada pasar asing, perusahaan yang paling produktif akan memutuskan untuk melayani pasar asing melalui FDI. Langkah ini dipilih ketika keuntungan dari menghindari biaya transportasi lebih besar ketimbang biaya pemeliharaan fasilitas di luar negeri. Sementara itu, perusahaan dengan produktivitas yang lebih rendah memilih untuk melakukan ekspor. Hal tersebut dinamakan proximity concentration trade-off. Dengan mewujudkan konsep tersebut dalam teori FDI horizontal, model dapat memprediksi bahwa pasar luar negeri lebih baik dilayani oleh ekspor adalah relatif terhadap penjualan FDI ketika gesekan perdagangan lebih rendah atau skala ekonomi lebih tinggi.

Terdapat pendapat lain mengenai FDI vertikal dan horizontal. FDI vertikal, dalam tulisan lain, diartikan sebagai suatu kondisi FDI yang terjadi ketika perusahaan multinasional membagi proses produksi secara internasional dengan meletakkan setiap tahapnya pada negara-negara yang dianggap dapat menyelesaikan tahap produksi tersebut dengan biaya yang rendah. Adapun FDI horizontal terjadi ketika perusahaan multinasional melakukan kegiatan produksi yang sama dengan negara induk di beberapa negara lain (Ainzenman dan Marion, 2001).

FDI vertikal dan horizontal dapat diklasifikasikan dalam dua bentuk. Bentuk pertama disebut sebagai merger dan akuisisi. Menurut Maksimovic dan Phillips dalam (Nayak dan Choudhury, 2014), pada bentuk ini, perusahaan memiliki izin untuk memanfaatkan komplementaritas dalam apa yang disebut firm-specific assets. Artinya, dalam pasar merger dan akuisisi, perusahaan heterogen diijinkan untuk menjual dan membeli aset perusahaan sebagai upaya memanfaatkan komplementaritas. Bentuk lainnya biasa disebut dengan greenfield FDI. Pada 
bentuk ini, perusahaan membangun kapasitas produksinya di luar negeri untuk menyebarkan asetnya di negara asing.

\section{Siklus Kehidupan Produk}

Model Siklus Kehidupan Produk (Product Life Cycle atau PLC) dianggap sebagai sebuah teori yang menjelaskan bahwa suatu produk akan mengalami tahap-tahap yakni, muncul, matang, dan mati. Penggunaan model Siklus Kehidupan Produk dalam teori perdagangan internasional, dikemukakan oleh Raymond Vernon, dalam beberapa tulisannya yang berjudul International Investment and International Trade in the Product Cycle (1966), Sovereign at Bay (1971), The Product Cycle Hypothesis in A New International Environment (1979), serta dalam Sovereignty at Bay, Ten years After (1981). Teori ini mengemukakan bahwa tahap "mati"-nya suatu produk dapat ditunda melalui perdagangan internasional dan melalui pengembangan industri nasional menjadi industri multinasional (Prapti, 1991).

Teori ini lahir pasca teori Klasik dan Neoklasik sehingga tidak terlalu menekankan diri pada doktrin Comparative Cost (Prapti, 1991). Sebagai teori yang diharapkan dapat memperbaiki teori-teori sebelumnya, ketimbang menekankan diri kepada Comparative Cost, model Siklus Kehidupan Produk ini lebih menekankan diri kepada hal-hal sebagai berikut.

a) dorongan melakukan inovasi dan penemuan yang ditimbulkan oleh adanya kekhawatiran dan harapan di pasar;

b) ketepatan waktu dalam melakukan inovasi dan penemuan;

c) arti penting komunikasi untuk memecahkan masalah ketidakpedulian terhadap produk dan ketidakpastian teknologi;

d) memanfaatkan skala ekonomis;

e) strategi untuk mencapai penguasaan pasar.

Teori PLC mempertimbangkan semua variabel yang mempengaruhi perdagangan internasional sebagai variabel yang dinamis. Artinya, variabel-variabel tersebut akan selalu berubah dari waktu ke waktu, dan perubahannya terjadi di dalam model. Dalam teori PLC, yang mengalami perubahan dari waktu ke waktu adalah kondisi dari permintaan dan penawaran komoditi perdagangan, karena variabelvariabel yang mempengaruhinya juga selalu mengalami perubahan. Contohnya seperti variabel penghasilan dan supply faktor produksi. Sebagai ilustrasi, pada mulanya satu tenaga kerja dapat memproduksi satu unit barang A, kemudian sebagai akibat dari perubahan teknologi, satu tenaga kerja dapat 
memproduksi dua unit barang A; keadaan ini sama saja seperti mengatakan bahwa suplai tenaga kerja telah naik dari satu unit menjadi dua unit (Prapti, 1991).

Model Siklus Kehidupan Produk menjadi lima tahapan yakni, pertumbuhan produk, pengenalan produk, pengembangan produk, pendewasaan produk serta penurunan produk (Komninos, 2002).

1) Tahap perkembangan produk

Tahap ini dimulai ketika perusahaan menemukan dan mengembangkan ide mengenai produk baru. Dalam tahap ini, dilakukan penafsiran berbagai informasi untuk kemudian dimasukkan sebagai unsur-unsur pembentuk produk baru. Sebelum diekspos ke target pelanggan dalam pasar uji, suatu produk biasanya mengalami beberapa perubahan yang melibatkan banyak uang dan waktu selama pengembangan. Produkproduk yang bertahan di pasar uji lantas diperkenalkan ke pasar nyata dan fase pengenalan produk dimulai. Selama fase pengembangan produk, penjualan bernilai nol dan pendapatan bernilai negatif.

2) Tahap pengenalan produk

Dalam tahap ini, pengeluaran besarbesaran dalam proses promosi dan pengiklanan pada umumnya terjadi.
Sebuah perusahaan harus siap untuk menghabiskan banyak uang dan hanya mendapatkan sebagian kecil dari uang yang dikeluarkan itu. Pengaturan distribusi mulai diperkenalkan. Keberadaan produk di setiap toko menjadi sangat penting dan dianggap sebagai tantangan besar. Jasa outsourcing dapat digunakan untuk menghindari tantangan ini. Pengaturan harga (pricing) juga dilakukan dalam tahap ini. Pada umumnya, ada dua strategi pengaturan harga. Pertama, perusahaan mengasumsikan bahwa konsumen tidak akan segan membayar mahal untuk sesuatu yang baru. Namun, dalam kurun waktu tertentu, kebijakan harga harus lebih kompetitif. Strategi kedua, perusahaan menganggap bahwa harga yang telah ditentukan sebelumnya merupakan yang paling mampu untuk memaksimalkan penjualan. Namun, strategi seperti ini menuntut pengetahuan pasar yang sangat baik mengenai produk apa yang membuat konsumen bersedia membayarnya dengan harga tertentu. Bagaimanapun, rangkaian proses yang terdapat dalam tahap ini memerlukan strategi pemasaran yang tepat. 
3) Tahap pertumbuhan produk

Dalam tahap ini, perusahaan dapat menikmati kepuasan ketika melihat produk lepas landas di pasar. Ini adalah waktu yang tepat untuk fokus pada peningkatan pangsa pasar. Jika produk telah diperkenalkan ke pasar, maka produk tersebut berada dalam posisi yang relatif mudah untuk mendapatkan pangsa pasar. Pasar baru yang berkembang dapat mengambil perhatian para kompetitor. Perusahaan harus selalu melakukan penawaran produk terkait, serta melakukan diferensiasi dari produk-produk serupa yang dikeluarkan oleh perusahaan lain. Promosi dan pengiklanan terus berlanjut. Mengatur tahap ini sangatlah penting. Estimasi yang akurat dalam memperkirakan kebutuhan konsumen akan menyumbang masukan penting ke dalam proses perencanaan produksi. Usaha meningkatkan ekspetasi pelanggan dan permintaan produk tidak akan berguna tanpa mengatur kapasitas produksi relatif.

4) Tahap kematangan produk

Periode ini adalah periode pengembalian tertinggi dari produk. Perusahaan yang telah mencapai sasaran pangsa pasar menikmati periode yang paling menguntungkan.

Sementara itu, perusahaan yang tertinggal di belakang tujuan pangsa pasarnya, harus mempertimbangkan kembali posisi pemasarannya ke pasar. Pada tahap ini, merek-merek baru akan muncul, sekalipun bersaing dengan jenis yang sama dari perusahaan yang sama pula. Perubahan model lebih sering terjadi. Periode ini adalah waktu untuk memanjangkan eksistensi produk. Pengaturan harga pada tahap ini menjadi naik-turun, juga seringkali diikuti dengan pemberian diskon yang ditujukan untuk mendapatkan konsumen baru. Pertempuran distribusi dilanjutkan dengan menggunakan saluran multidistribusi.

5) Tahap penurunan produk

Pada tahap ini, perusahaan mulai menarik variasi produk dari pasar yang lemah di posisi pasar mereka. Tahap ini harus dilakukan dengan hati-hati karena variasi produk apa yang menghasilkan pendapatan jarang terlihat. Harga harus dijaga agar tetap kompetitif dan promosi harus ditarik kembali pada tingkat yang membuat kehadiran produk tampak di pasar serta guna mempertahankan pelanggan "setia". 
Di tahap ini, proses distribusi menyempit dalam arti saluran distribusi dasar harus tetap efisien, sedangkan saluran distribusi alternatif harus ditinggalkan.

Sementara itu, pendapat lain membagi Siklus Kehidupan Produk ke dalam tiga tahapan saja. Tahapan tersebut terdiri atas pengenalan inovasi, kematangan, dan tahap akhir yang ditandai dengan standarisasi produk (Nayak dan Choudhury, 2014).

1) Tahap pengenalan inovasi

Pada tahap ini, produk baru ditemukan, diproduksi dan dijual. Jika penjualan sukses, produksinya akan bertambah dan pasar baru akan dilirik oleh perusahaan untuk mengembangkan ekspor.

2) Tahap kematangan

Pada tahap kematangan, elastisitas harga permintaan untuk produk relatif rendah. Permintaan produk meningkat pada pasar asing. Karena itu, kompetitor muncul. Pada tahap ini pula, perusahaan mulai dikenal secara internasional.

3) Tahap akhir

Tahap ini ditandai dengan standarisasi produk. Teknik produksi mulai dikenal oleh masyarakat. Investasi bergerak ke lokasi manapun di dunia di mana biaya berada pada tingkat serendah mungkin. Akhirnya, produk dapat diekspor ke negara yang pertama kali memproduksi produk tersebut. Negara pengekspor berubah menjadi negara pengimpor pada tahap ini.

\section{Metode Penelitian}

Metode yang digunakan dalam penelitian ini ialah metode kualitatif. Penelitian kualitatif merupakan penelitian yang mengutamakan segi kualitas data. Penelitian kualitatif mempelajari catatan penelitian lapangan. Analisis data kualitatif berlangsung secara berkelanjutan sejak peneliti mulai memasuki lapangan dan arah penelitian dapat berubah sesuai dengan hasil analisis di lapangan (Sunarto, 2004). Bogdan dan Tailor seperti yang dikutip oleh Moeleong dalam (Subandi, 2011), mendefinisikan metodologi kualitatif sebagai prosedur penelitian yang menghasilkan data deskriptif berupa katakata tertulis atau lisan atau dari bentuk tindakan kebijakan. Analisis data kualitatif merupakan analisis data yang berbentuk penjabaran non statistik dengan menggunakan penalaran berdasarkan teori yang berhubungan dengan masalah yang dianalisis (A. A. dan Effendi, 2013).

Dalam penelitian ini, teknik analisis data yang digunakan adalah deskriptif. Teknik analisis data deskriptif berusaha menjelaskan data yang diperoleh dari 
lapangan secara rinci. Teknik analisis data deskriptif digunakan untuk memberikan gambaran-gambaran yang khusus dalam menjawab rumusan masalah pada penelitian. Dalam penelitian ini ialah FDI Indonesia di Nigeria periode 2014-2017, terutama pada PT. Indofood Sukses Makmur.

\section{Pembahasan}

Pasar Nigeria merupakan salah satu yang paling potensial di Afrika. Dengan jumlah penduduk terbanyak seantero Afrika, Nigeria memiliki tingkat konsumsi penduduk yang tinggi. Di samping itu, sumber daya alam dan manusia yang melimpah dan belum sepenuhnya dieksploitasi membuat negara ini menjadi semakin menarik untuk dijadikan sasaran investasi.

Mayoritas perusahaan yang berinvestasi di Nigeria memilih sektor barang konsumsi untuk komoditinya. Alasannya karena jumlah penduduk Nigeria besar, tetapi industri pengolahannya masih belum terbangun secara maksimal. Investasi di bidang barang konsumsi juga dianggap sangat prospektif karena dengan jumlah penduduk Nigeria yang besar menyebabkan daya beli naik sehingga peluang investasi di industri pengolahan terbuka lebar. Industri pengolahan seperti bahan makanan sangat berguna untuk memenuhi kebutuhan pokok masyarakat sehingga hampir tidak mungkin industri ini mati, mengingat pertumbuhan penduduk pun terus melaju (Ningsih S., 2016).

Produk makanan yang sangat terkenal di Nigeria salah satunya adalah Indomie, mie instan yang diproduksi oleh De United Foods Industries Ltd. Seperti yang telah dijelaskan pada Bab I, Indomie di Nigeria memiliki beberapa perbedaan dengan Indomie di Indonesia. Serangkaian modifikasi yang ditujukan agar orang Nigeria tidak terlalu asing dengan mie instan itu membuat De United Foods Industries Ltd berhasil menarik hati para konsumen di Nigeria. Produk lain milik perusahaan ini ialah Power Pasta (spageti), Power Oil (minyak sayur), dan Minimie (mie instan).

De United Foods Industries Ltd (DUFIL) merupakan perusahaan patungan antara Grup Salim, Indonesia (induk perusahaan PT. Indofood Sukses Makmur) dengan Grup Tolaram (Singapura). Merujuk pada laman resmi DUFIL, perusahaan ini bermula pada tahun 1995. DUFIL didirikan dengan tujuan untuk memproduksi merk mie instan Indomie. Di tahun berikutnya, dimulailah operasi DUFIL di Ota. Pada 2001, perusahaan ini bergabung dengan DUFIL Prima Foods Ltd di Choba, Port Harcourt, yang baru 
mulai beroperasi pada di tahun berikutnya.

Tahun 2004, penjualan Indomie di Nigeria mencapai 1 juta karton per bulan. Insignia Print Technology LFTZ Enterprise bergabung sebagai anak perusahaan DUFIL Prima Foods Ltd di Lagos. Di tahun berikutnya, DUFIL Prima Foods Ltd diubah menjadi Perseroan Terbatas Publik (Plc) sekaligus sebagai perusahaan induk. Di tahun itu pula, divisi seasoning (pembumbuan) mulai berjalan di Ota. Tahun 2010, produksi Indomie mencapai angka 1 milyar dus. Setahun setelahnya, Northern Noodles Ltd bergabung sebagai anak perusahaan dari DUFIL Prima Foods $P l c$ di Kaduna sekaligus mulai beroperasi.

Joint Venture atau patungan menurut UNIDO merujuk kepada kombinasi dari dua atau lebih partner yang memiliki motif pokok yang berbeda namun memiliki tujuan strategis yang sama (Jayady, dkk., 2016). Joint ventures diklasifikasikan UNIDO ke dalam empat tipe, yaitu:

\section{1) Contractual joint ventures}

Tipe ini ditandai dengan lebih dari dua perusahaan yang menjadi partisipan, serta durasi yang pendek atau sesuai dengan batasan waktu sebuah proyek dalam penyelenggaraannya. Contractual joint venture sering diimplementasi pada baik pada lingkup teknik sipil dan konstruksi atau industri penyuplai perlengkapan pada pembangunan infrastruktur dalam suatu negara.

\section{2) Equity joint ventures}

Tipe ini dapat diartikan sebagai aliansi bisnis yang memiliki ciri lebih permanen dalam kerjasama sering disebut juga sebagai incorporated joint venture dikarenakan partisipan yang terlibat sepakat membentuk legal entitas bisnis baru yang biasa disebut dengan joint venture company alias perusahaan patungan.

\section{3) Cooperative joint ventures}

Merupakan bentuk aliansi bisnis antara pihak pemerintah dan swasta yang sering dilakukan pada negaranegara berkembang.

4) Restructuring joint ventures

Merupakan tipe aliansi bisnis yang biasanya dibentuk dalam durasi tertentu (menengah) oleh pihak perusahaan yang terlibat dan telah direncanakan akuisisi salah satu pihak di atas pihak lain yang terlibat. Mengacu pada pengertian tersebut, De United Foods Industries Ltd termasuk pada klasifikasi kedua yakni equity joint ventures. Alasannya adalah karena baik Grup Salim maupun Grup Tolaram sejak 
awal sepakat untuk mendirikan sebuah perusahaan dengan legal entitas bisnis yang baru di Nigeria.

Dalam kerangka teori Investasi Asing Langsung, De United Foods Industries Ltd dapat diklasifikasikan sebagai bentuk FDI horizontal. Kedua perusahaan yang pertama kali membentuk perusahaan patungan ini telah sepakat untuk membuka perusahaan baru di luar negara kedua perusahaan asal. Perusahaan itu diberikan hak untuk memproduksi dan mendistribusikan produknya sendiri ke pasar negara tuan rumah, dalam hal ini, Nigeria. Hal tersebut sesuai dengan konsep FDI horizontal bahwa FDI horizontal merupakan bentuk investasi dalam produksi di luar negeri yang dirancang untuk melayani konsumen asing (Nayak dan Choudhury, 2014).

Ini juga senada dengan apa yang dikemukakan oleh Ainzenman dan Marion, bahwa FDI horizontal terjadi ketika perusahaan multinasional melakukan kegiatan produksi yang sama dengan negara induk di beberapa negara lain. DUFIL melakukan produksi untuk produk yang sama dengan perusahaan asalnya, Indomie, yang semula diproduksi oleh PT. Indofood Sukses Makmur di Indonesia (Ainzenman dan Marion, 2001).

Lebih lanjut, DUFIL dapat diklasifikasikan ke dalam jenis FDI greenfield. FDI greenfield memungkinkan perusahaan membangun kapasitas produksinya di luar negeri untuk menyebarkan asetnya di negara asing (Nayak dan Choudhury, 2014). Maksudnya adalah, pendirian perusahaan itu di Nigeria adalah berdasarkan modal asing yang sepenuhnya dimiliki oleh investor asing. Negara penerima hanya sebatas penyedia lahan saja.

Dalam perkembangannya, perusahaan ini bergabung dengan DUFIL Prima Foods Ltd (sekarang DUFIL Prima Foods Plc). Artinya, terjadi merger (penggabungan) yang menyebabkan De United Foods Industries Ltd menjadi anak perusahaan dari DUFIL Prima Foods Plc.

Pada periode 2014-2017, produk PT. Indofood Sukses Makmur yang merajalela di pasar Nigeria berada pada tahap kematangan. Pada periode ini, Indomie, sebagai produk andalan perusahaan DUFIL, telah tersebar luas ke seluruh pasar Nigeria. Produk mie instan milik PT. Indofood Sukses Makmur pada 2017 telah menguasai 70\% pasar Nigeria (Sugianto, 2017) dan (Fauzi, 2017). Periode ini merupakan masa yang paling menguntungkan (Komninos, 2002). Salah satu alasannya adalah permintaan produk meningkat pada pasar asing sehingga mulai dikenal secara internasional (Nayak dan Choudhury, 2014). Namun, pada tahap 
ini pula, merek-merek baru akan muncul, sekalipun bersaing dengan jenis yang sama dari perusahaan yang sama pula. Contoh konkretnya adalah merek Minimie yang juga diproduksi oleh DUFIL. Eksistensi produk harus diperhatikan pada tahap ini guna menghindari masuknya produk ke dalam tahap penurunan.

Tahap kematangan ini berarti tahap dimana merek harus diposisikan ulang. Tujuannya adalah untuk meraih segmen baru di pasar (Jasin, 2011). Ada beberapa strategi yang dapat dilakukan guna mempertahankan eksistensi produk pada tahap ini. Pertama, menyesuaikan ukuran, warna, dan kemasan sesuai permintaan konsumen. Mengatur ulang ukuran, warna, dan kemasan sesuai dengan permintaan konsumen di pasar dilakukan karena selera konsumen senantiasa berubah dari waktu ke waktu, maka dibutuhkan penyesuaian produk terhadap kebutuhan konsumen. Pada tahap ini, periklanan harus tetap dilakukan dengan menggunakan perbandingan terhadap merek lain guna memiliki ciri khas tersendiri yang berbeda dengan merek lain. Distribusi hanya perlu untuk dipertahankan, dan harga yang dianjurkan pada periode ini adalah menggunakan transaksi harga (Jasin, 2011).

\section{Simpulan}

Berdasarkan pembahasan yang telah diuraikan pada bab sebelumnya, dapat ditarik kesimpulan bahwa PT. Indofood Sukses Makmur yang berdiri bersama Grup Toleram (Singapura) di Nigeria dengan nama De United Foods Industries Ltd merupakan perusahaan dengan model FDI horizontal. Perusahaan ini termasuk dalam kategori FDI greenfield. Namun, pada perkembangannya, terjadi merger antara perusahaan De United Foods Industries Ltd dengan DUFIL Prima Foods Plc.

Menurut teori Siklus Hidup Produk, produk mie instan milik PT. Indofood Sukses Makmur yang diproduksi oleh De United Foods Industries Ltd di Nigeria berada pada tahap kematangan. Ada beberapa strategi untuk mempertahankan eksistensi produk di pasar pada tahap kematangan ini seperti: menyesuaikan ulang ukuran, warna, dan kemasan produk; membuat iklan yang berbeda dari pesaing; mempertahankan distribusi serta; menggunakan transaksi harga.

\section{Saran}

Strategi pemasaran pada tahap kematangan seperti yang telah dituliskan pada bagian "Simpulan" sebaiknya dilaksanakan guna mencegah masuknya produk ke dalam tahap penurunan. Ini seharusnya dilakukan dengan baik, karena 
biaya yang dikeluarkan akan relatif lebih rendah ketimbang membiarkannya jatuh ke tahap penurunan dan harus menciptakan produk baru. Biaya yang dikeluarkan pada tahap pengembangan dan perkembangan produk akan jauh lebih mahal dibandingkan dengan mempertahankan produk yang sudah matang.

\section{Referensi}

A. A., Iskandar. (2013). Pengaruh Brand Image Produk terhadap Kesetiaan Pelanggan Pengguna Internet Modem Smartfren Connex di Bandar Lampung. Jurnal Manajemen dan Bisnis, 4, 24-42. Dipetik 17 November 2018 dari https://media.neliti.com/media/publi cations/112259-ID-pengaruh-brandimage-produk-terhadap-kes.pdf

Ainzenman, Joshua, dan Nancy Marion. (2001). The Merits of Horizontal Versus Vertical FDI in The Presence of Uncertainty. NBER Working Paper Series. Cambridge: National Bureau of Economic Research. Dipetik 18 November 2018 dari https://www.nber.org/papers/w8631. pdf

BBC News. (2018). Nigeria Country Profile. Dipetik 17 November 2018 dari

https://www.bbc.com/news/worldafrica-13949550

De United Foods Industries Limited._. About Us: History. Dipetik 18 November 2018 dari http://www.dufil.com/abouthistory.html

De United Foods Industries Limited.___ Our Brands:

Indomie Flavours. Dipetik 18 November 2018 dari http://www.dufil.com/brands-

flavours.html

Fauzi, Achmad. (2017). Ini Alasan Indomie Sangat Digemari di Nigeria. Dipetik pada 17 November 2018 dari https://ekonomi.kompas.com/read/20 17/06/03/113000926/ini.alasan.indo mie.sangat.digemari.di.nigeria

Jayady, Arman, dkk. (2016). Tipologi Joint Operation pada Proyek Konstruksi di Indonesia. Prosiding Konferensi Nasional Pascasarjana Teknik Sipil (KNPTS). Dipetik 18 November 2018 dari https://www.researchgate.net/publica tion/315379256_TIPOLOGI_JOINT _OPERATION_PADA_PROYEK_ KONSTRUKSI_DI_INDONESIA/d ownload

Kementrian Luar Negeri Republik Indonesia.__. Profil Negara dan Kerjasama: Nigeria. Dipetik 17 November 2018 dari https://www.kemlu.go.id/id/kebijaka n/detail-kerjasama-

bilateral.aspx $? \mathrm{id}=125$

Kementrian Perdagangan Republik Indonesia. (2018). Neraca Perdagangan Indonesia dengan Nigeria Periode 2013-2018. Dipetik 17 November 2018 dari http://www.kemendag.go.id/id/econo mic-profile/indonesia-exportimport/balance-of-trade-with-tradepartner-country?negara $=237$

Komninos, Ioannis. (2002). Product Life Cycle Management. Thessaloniki: Urban and Regional Innovation Research Unit Faculty of Engineering Aristotle University of Thessaloniki. Dipetik 16 November 2018 dari https://www.amieindia.in/studymaterials/product-life-cycle.pdf

M. P., Istman. (2017). Jokowi Kaget Indomie Rasa Ini Laris di Nigeria Porsinya Besar. Dipetik 18 November 2018 dari 
https://nasional.tempo.co/read/88264

7/jokowi-kaget-indomie-rasa-inilaris-di-nigeria-porsinya-

besar/full\&view $=$ ok

Nayak, Dinkar, dan Rahul N. Choudhury. (2014). A Selective Review of Foreign Direct Investment Theories. Asia-Pacific Research and Training Network on Trade Working Paper No 143

Nigerian Investment Promotion Commission. (2016). Priority Sectors. Dipetik 17 November 2018 dari

https://www.nipc.gov.ng/prioritysectors/

Nigerian Investment Promotion Commission. (2016). Reasons To Invest in Nigeria. Dipetik 17 November 2018 dari https://www.nipc.gov.ng/reasonsinvest-nigeria/

Ningsih S., Sri Kurnia Fitri. (2016). Kerjasama Nigeria-Indonesia Dalam Bidang Investasi Makanan Tahun 2008-2014. JOM FISIP, 3, 1-11. Dipetik 18 November 2018 dari http://download.portalgaruda.org/arti cle.php? article $=439286 \& \mathrm{val}=6444 \&$ title=KERJASAMA \%20NIGERIAINDONESIA \%20DALAM\%20BID ANG\%20INVESTASI\%20MAKAN AN\%20TAHUN\%202008-2014

Organization for Economic Co-Operation and Development. (2008). OECD Benchmark Definition of Foreign Direct Investment Fourth Edition. Dipetik 16 November 2018 dari https://www.oecd.org/daf/inv/invest mentstatisticsandanalysis/40193734. pdf

Prapti, Endang Sri. (1991). Derivasi Teori Siklus Kehidupan Produk (Product Life Cycle Theory): Jawaban atas kegagalan Teori Hechscher-Ohlin. Jurnal Ekonomi dan Bisnis Indonesia, 6. Dipetik 17 November 2018 dari https://jurnal.ugm.ac.id/jieb/article/vi ew/40087

Safitriani, Suci. (2014). Perdagangan Internasional dan Foreign Direct Investment di Indonesia. Buletin Ilmiah Litbang Perdagangan, 8, 93-116. Dipetik 15 November 2018 dari http://www.kemendag.go.id/files/pdf /2014/11/19/-1416397117.pdf

Subandi. (2011). Deskripsi Kualitatif sebagai Satu Metode dalam Penelitian Pertunjukan. Harmonia, 11, 172-179. Dipetik 17 November 2018 dari http://download.portalgaruda.org/arti cle.php?article $=135923 \& \mathrm{val}=5651$

Sugianto, Danang. (2017). Indomie kuasai 70\% Pangsa Pasar Nigeria. Dipetik pada 17 November 2018 dari https://finance.detik.com/bursa-danvalas/d-3518735/indomie-kuasai-70pangsa-pasar-nigeria

Sunarto, Kamanto. (2004). Pengantar Sosiologi Edisi Revisi. Jakarta: Lembaga Penerbit Fakultas Ekonomi Universitas Indonesia

United Nations Conference on Trade and Development. (2018). Country Fact Sheets 2018. Dipetik 17 November 2018 dari https://unctad.org/en/Pages/DIAE/W orld\%20Investment\%20Report/Coun try-Fact-Sheets.aspx

United Nations Conference on Trade and Development. (2017). World Investment Report. Geneva: United Nations Publication. Dipetik 17 November 2018 dari https://unctad.org/en/PublicationsLib rary/wir2017_en.pdf

Wargadiredja, Arzia Tivany. (2017). Alasan Indomie Digilai Penduduk Nigeria. Dipetik 17 November 2018 dari https://www.vice.com/id_id/article/ yp7nqv/alasan-indomie-digilaipenduduk-nigeria 